\title{
PENGGUNAAN KERANG GANGSING (Sesarma reticulatum) DAN BIJI WIIEN DALAM RANSUM, PENGARUHNYA TERHADAP KANDUNGAN OMEGA-6 DAN OMEGA-3 DI DALAM KUNING TELUR ITIK
}

\author{
Ema Winarti, Niniek Kusuma Wardhani dan Almad Musofie
}

\section{INTISARI}

Penelitian bertujuan untuk mengetahui pengaruh pemberian biji wijen dan kerang gangsing pada itik terhadap kandungan asam lemak omega- 6 dan omega-3 di dalam kuning telur. Penelitian menggunakan 60 ekor itik yang sedang produksi, dibagi ke dalam 4 kandang. Rancangan percobaan menggunakan Bujur Sangkar Latin dengan empat perlakuan pakan. Perlakuan $(\mathrm{A})$ kerang gangsing $0 \%$ dan biji wijen $4 \%$, (B) kerang gangsing $15 \%$ dan biji wijen $2 \%$, (C) kerang gangsing $30 \%$ dan biji wijen $0 \%$, (D) kerang gangsing $0 \%$ dan biji wijen $0 \%$ sebagai kontrol. Pergantian perlakuan tiap kandang dilakukan setiap 4 minggu sekali. Produksi telur dicatat setiap hari, analisis kandungan omega-3, omega- 6 dan wama kuning telur dilakukan pada minggu ke-4 setelah pemberian pakan perlakuan. Hasil penelitian menunjukkan bahwa produksi telur tidak berbeda nyata $(\mathrm{P}<0,05)$ antar perlakuan. Skor warna kuning telur perlakuan $\mathrm{C}$ (9,3) lebih tinggi secara nyata ( $P<0,05)$ dibanding perlakuan $A(7,6)$ dan $D(4,5)$. Kandungan omega-3 perlakuan $B(118,61 \mathrm{mg} / 2$ butir $)$ dan $C(201,20 \mathrm{mg} / 2$ butir) nyata lcbih tinggi $(P<0,05)$ dibanding perlakuan $\mathrm{A}(94,89 \mathrm{mg} / 2$ butir). Kandungan omega 6 perlakuan $\mathrm{A}(1289,82 \mathrm{mg} / 2$ butir $)$ nyata lebih tinggi dibanding perlakuan B $(599,22 \mathrm{mg} / 2$ butir) dan perlakuan C $(579,89 \mathrm{mg} / 2$ butix). Penelitian ini dapat disimpulkan bahwa pemberian kerang gangsing $15 \%$ dan $30 \%$ dalam ransum itik dapat meningkatkan kandungan omega-3, penggunaan wijen $2 \%$ dan $4 \%$ dapat meningkatkan kandungan omega- 6 .

(Kata kunci: Sesarma reticulatum, Biji wijen, Teluritik, Omega-3, Omega-6)

Buletin Peternakan 31 (1): 1-6, 2007

'Balai Pengkajian Teknologi Pertanian Yogyakarta. 


\title{
THE EFFECT OF UTILIZATION OF GANGSING COCKLE (Sesarma reticulatum) AND SESAME SEED IN RATION ON OMEGA-6 AND OMEGA-3 CONTENT IN DUCK EGG YOLK
}

\begin{abstract}
The aim of this experiment was to investigate the influence of sesame seed and gangsing cockle in duck ration on the content of omega-6 and omega-3 in egg yolk. Sixty $(60)$ productive ducks were used in the experiment. They were divided into four groups and places in 4 cages ear each groups. The feed treatments were as follows: treatments (A) gangsing cockle $0 \%$ and sesame seed $4 \%$, (B) gangsing cockle $15 \%$ and sesame seed $2 \%$, (C) gangsing cockle $30 \%$ and sesame seed $0 \%$, (D) gangsing cockle $0 \%$ and sesame seed $0 \%$ as a control. The treatment for each group was changed every four weeks. Data of egg production were recorded every day. The content of omega-6, omega-3 and egg yolk werc analyzed four weeks after feeding treatment. The results indicated that the egg production did not differ among the treatments. Color score of cgg yolk from bind of treatment $C(9.3)$ was significantly higher $(P<0.05)$ compared to treatment $A(7.6)$ and D (4.5). Obstetrical omega-3 at treatment B (118.6 mg/2 eggs) and C (201.20 mg/2 eggs) was higher $(\mathrm{P}<0.05)$ compared to treatment A $(94.89 \mathrm{mg} / 2 \mathrm{eggs})$. Content of omega- 6 treatment $\mathrm{A}$ (1289.82 $\mathrm{mg} / 2 \mathrm{eggs})$ was higher compared with treatment B $(599.22 \mathrm{mg} / 2 \mathrm{eggs})$ and treatment $\mathrm{C}$ (570.89 mg/2 eggs). In conclusion gangsing $15 \%$ and $30 \%$ level in duck ration could increase obstetrical omega-3, where as the use of sesame seed $2 \%$ and $4 \%$ increased omega- 6 content.
\end{abstract}

(Key words: Sesarma reticulatum, Sesame seed, Duck egg, Omega-3, Omega-6)

\section{Pendahuluan}

Isu negatif tentang telur yang dibubungkan dengan kandungan kholesterol dan penyakit jantung, mendorong para ahli intuk melakukan berbagai penelitian. Kholesterol mempunyai fungsi ganda, yaitu di satu sisi diperlukan dan sisi lain membahayakan tergantung pada berapa banyak terdapat dalam tubuh dan di bagian mana. Kholesterol merupakan komponen esensial membran struktural semua sel dan merupakan komponen utama sel otak dan saraf. Kholesterol akan membahayakan tubuh apabila terdapat terlału banyak di dalam darah, karena dapat membentuk endapan pada dinding pembutuh darah sehingga menyebabkan penyempitan pembuluh darah yang dinamakan arteriosklerosis. Penyempitan apabila terjadi di pembuluh darah jantung dapat menyebabkan penyakit jantung koroner dan bila terjadi di pembuluh darah otak menyebabkan penyakit serebrovaskular (Almatsier, 2003).

Penelitian di bidang nutrisi ternak telah banyak dilakukan untuk meningkatkan kandungan omega-3 dan omega- 6 dalam telur melalui manipulasi pakan. Hasil penelitian tahun 1994 memberikan gambaran bahwa secara umum jumlah atau besarnya polyunsaturated fatty acid (PUFA) rantai panjang termasuk di dalamnya DHA di dalam kuning telur merupakan refleksi dari jumlah yang diberikan dalam pakan (Oh et al., 1994). Hasil yang sama didapatkan olch Chen et al. (1999), yang menunjukkan bahwa kandungan EPA dan DHA dalam kuning telur meningkat apabila jumlah minyak ikan yang kaya akan EPA dan DHA yang diberikan dalam ransum ditingkatkan. Seminggu setelah pemberian ransum tersebut, telah terjadi kenaikan kandungan omega-3 dalam kuning telur dan stabil pada minggu ketiga. Hasil penelitian Chen et al. (1999) menyebutkan bahwa kandungan EPA dalam minyak ikan yang digunakan tebih tinggi dibanding kadar 
DHA, tetapi di dalam telur yang dihasilkan, kadar DHA lebih tinggi dibanding kadar EPA.

Asam lemak omega-3 yang mempunyat arti khusus dalam ilmu gizi adalah alfa-asam linolenat (C 18:3 ( -3 ) serta turunannys asam Eikosapentanoat/EPA (C:20 $\varphi-3)$ dan DokosaheksanoavDHA (C) 22:6 ( $(-3)$, Asam linolenat merupakan asam lemak esensial, yaitu dibutuhkan oleh tubuh tetapi tubuh tidak dapat mensintesanya. EPA dan DHA bukan merupakan asam lemak esensial karena tubuh dapat mensintesanya. Ketiga asam lemakini merupakan asam lemak tidak jenuh. Berbagai pendapat menyebutkan, bahwa kandungan asam lemak omega-3 di dalam telur dapat ditingkatkan dengan memasukkan sumber asam lemak umega-3 di dalam ransum. Cherian dan Sim (1992) menyatakan bahwa mengkonsumsi minyak ikan yang kaya omega- 3 sangat penting dalam mendukung perkembangan sistem syaraf otak padà mamalia dan unggas. Disebutkan juga olch Chen et al. (1999) bahwa EPA dan DHA berpengaruh baik pada keschatan, terutama pada perkembangan sel otak pada masa pertumbuhan, menurunkan lemak dan kholesterol darah, menurunkan daya adesif Uarah terhadap dinding pembuluh darah, memperbaiki sirkulasi darah, kesehatan mata dan menghambat terjadinya jantung koroner hubungannya dengan sistem cardio vasculer.

Wijen (Sesamum indicum L.) merupakan salah satm jenis biji-bijian yang mengandung lemak cukup tinggi di samping kandungan protein yang tinggi pula. Kandungan lemak wijen berkisar antara 35$63 \%$ dan protein $19-25 \%$ (Soenardi dan Romli, 1996). Kandungan lemak yang tinggi diikuti juga dengan kandungan asam lemak tidak jenuh yang tinggi pula yaitu sebesar $85,76 \%$ (Saroso, 1992) sehingga wijen merupakan salah satu sumber lemak yang bermutu tinggi. Bagian terbesar dari asam lemak tidak jenuh pada wijen adalah asam oleat yaitu sebesar $45,4 \%$ dan linoleat (omega-6) sebesar $40,4 \%$.

Kerang gangsing (Sesarma reticulatum) adalah biota laut dengan kandungan lemak kasar sebesar $17 \%$ dan protein kasar 27\% (Winarti et al., 2002). Kerang gangsing juga mengandung asam lemak omega-3 sebesar $9,08 \%$ area (Soeharsono et al., 2002). Kerang gangsing banyak terdapat di muara sungaj terutama pada waktu musim kemarau. Peternak itik di wilayah pantai selatan Kabupaten Bantul dan Kulon Progo telah banyak memanfaatkan biota laut ini scbagai baban pakan.

Penggunaan kerang gangsing (Sesarma reticulatum) dan biji wijen (Sesamum indicum $L$ ) dalam ransum itik, diharapkan mampu meningkatkan kualitas asam lemak di dalam kuning telur yang dihasilkan.

\section{Materi dan Metode}

Penelitian menggunakan Rancangan Bujur Sangkar Latin dengan empat perlakuan (4x4), Enam puluh ekor itik dibagi menjadi 4 kelompok perlakuan pakan, masing-masing kelompok 15 ekor itik. Penclitian dilakukan selama 4 bulan, masing-masing periode dilaksanakan selama 30 hari. Susunan ransum. seperti tertera pada Tabel 1. Parameter yang diamati meliputi produksi telur dan kualitas telur. Produksi telur dihitung tiap hari, pengamatan terhadap warna kuning telur dan kandungan omega- 3 serta omega- 6 dilakukan pada minggu ke-4 setelah pemberian ransum perlakuan. Warna kuning telur dibandingkan dengan Colour Yolk Fan, analisis kandungan omega-3 dan omega-6 menggunakan metode kromatografi. Data hasil pengamatan apabila ada perbedaan nyata antar perlakuan maka dilanjutkan dengan Uji Beda Nyata Terkecil (BNT) pada taraf $5 \%$. 
Tabel 1. Ransum itik pada masing-masing perlakuan (Duck ration in each treatment)

\begin{tabular}{lrrrr}
\hline \multirow{2}{*}{ Bahan pakan (Ingredient) } & \multicolumn{5}{c}{ Perlakuan (Treatments) } \\
\cline { 2 - 5 } & A & B & C & $\begin{array}{r}\text { D (Kontrol) } \\
\text { (Control) }\end{array}$ \\
\hline Katul (Rice bran) $(\%)$ & 60 & 53 & 47 & 75 \\
Jagung (Maize) $(\%)$ & 15 & 15 & 15 & 0 \\
Konsentrat (Concentrate feed) (\%) & 21 & 15 & 8 & 25 \\
Kerang gangsing (Sesarma reticulatum) (\%) & 0 & 15 & 30 & 0 \\
Biji wijen (Sesame seed) $(\%)$ & 4 & 2 & 0 & 0 \\
\hline
\end{tabular}

\section{Hasil dan Pembahasan}

Kandungan nutrisi ransum masingmasing periakuan selama penelitian tertera pada Tabel 2. Kandungan protein kasat perlakuan $\mathrm{C}$ paling tinggi dibanding dari tiga perlakuan lainnya, tetapi kandungan lemak paling rendah, Kandungan kalori dari keempat perlakuan hampir sama yaitu antara 2640$2654 \mathrm{kal} / \mathrm{kg}$.

Produksi telur, warna kuning telur, kandungan omega-3 dan omega-6 kuning telur hasil penelitian tertera di dalam Tabel 3 . Data dalam Tabel 3 menunjukkan bahwa produksi telur tidak berbeda antar perlakuan. Hal ini disebabkan oleh ransum yang disusun dari masing-masing perlakuan mengandung protein dan energi yang hampir sama.

Skor warna kuming telur menunjukkan perbedaan yang nyata $(\mathrm{P}<0,05)$. Skor warna kuning telur paling tinggi adalah perlakuan C yaitu ransum yang menggunakan kerang gangsing paling tinggi $(30 \%)$. Warna kuning telur perlakuan $\mathrm{C}$ tidak berbeda nyata dengan perlakuan $B$ yaitu ransum dengan 15\% kerang gangsing dan $2 \%$ wijen. Ransum tanpa kerang gangsing dan wijen mempunyai warna kuning telur paling rendah $(4,5)$. Warna kuning telur sangat dipengaruhi oleh pakan utamanya pada pakan yang tinggi akan xanthophyl dan pro vitamin A. Beta-karoten merupakan salah satu provitamin A yang berpengaruh pada warna kuning apabila terdapat dalam jumlah yang cukup dalam ransum unggas, Beta-karoten banyak terdapat pada jagung kuning, sayuran berwarna kuning dan hijau. Dalam pengkajian ini warna kuning telur selain disebabkan oleh beta-karoten jagung juga pengaruh dari kerang gangsing. Tingginya kandungan lemak dalam kerang gangsing, dimungkinkan diikuti dengan kandungan xanthophyl dan vitamin A yang terlarut di dalamnya. Hal ini dapat dilihat pada perlakuan $\mathrm{C}$ dengan kerang gangsing $30 \%$ mempunyai nilai kuning telur lebih tinggi (skor nilai kuning telur 9,3) dibanding perlakuan A (skor nilai kuning telur 7,6 ) dengan susunan ransum $0 \%$ kerang gangsing.

Kandungan asam lemak rantai panjang dalam kuning telur itik hasil penelitian ini dapat dilihat bahwa kandungan omega-3 dan omega-6 dalam kuning telur nyata $(P<0,05)$ dipengaruhi oleh ransum tiap-tiap perlakuan Kandungan asam lemak omega- 3 kuning telur pada ransum yang menggunakan kerang gangsing $15 \%$ (perlakuan A) sebcsar 118,61 $\mathrm{mg} / 2$ butir telur dan perlakuan B (kerang gangsing $30 \%$ ) sebesar $201,20 \mathrm{mg} / 2$ butir telur febih tinggi dibanding ransum tanpa kerang gangsing (perlakuan A dan D) yaitu sebesar $94,89 \mathrm{mg} / 2$ butir telur dan $77,31 \mathrm{mg} / 2$ butir telur, Kandungan omega- 3 yang tinggi pada perlakuan B dan C disebabkan karena ransum mengandung kerang gangsing yang merupakan sumber omega-3. Kerang gangsing mengandung asam lemak omega-3 sebesar $9,082 \%$ area (Soeharsono et $\mathrm{al}$, 2002). 
Tabel 2. Kandungan gizi ransum masing-masing perlakuan (Nutrient content in each treatment)

\begin{tabular}{lrrrrr}
\hline \multirow{2}{*}{ Kandungan nutrisi (Nutrient content) } & \multicolumn{4}{c}{ Perlakuan (Treatments) } \\
\cline { 2 - 6 } & $\mathrm{A}$ & $\mathrm{B}$ & $\mathrm{C}$ & $\begin{array}{r}\text { D (Kontrol) } \\
\text { (Control) }\end{array}$ \\
\hline Protein kasar (Crude protein) ("\%) & 16,8 & 17,2 & 17,4 & 18,0 \\
Lemak kasar (Crude fat) $(\%)$ & 9,2 & 9,7 & 10,2 & 7,0 \\
Encrgi (Energy) (Kal//kg) (Cal/kg) & 2647 & 2654 & 2644 & 2640 \\
\hline
\end{tabular}

Tahel 3. Produksi dan kualitas telur masing-masing perlakuan (Quantity and quality of eggs in each treatment)

\begin{tabular}{|c|c|c|c|c|c|}
\hline \multirow{2}{*}{$\begin{array}{l}\text { Perlakuan } \\
\text { (Treatments) }\end{array}$} & \multirow{2}{*}{$\begin{array}{l}\text { Produksi telur } \\
\text { (Egg } \\
\text { production) } \\
(\%)\end{array}$} & \multirow{2}{*}{$\begin{array}{c}\text { Skor warna } \\
\text { kuning telur } \\
\text { (Scone of yolk } \\
\text { color) }\end{array}$} & \multicolumn{3}{|c|}{$\begin{array}{l}\text { Asam lemak (mg/2 butir telur) } \\
\text { (Fatty acid ( } \mathrm{mg} / 2 \text { eggs }))\end{array}$} \\
\hline & & & Omega-3 & Omega -6 & $\begin{array}{l}\text { Omega-3: } \\
\text { Omega-6 }\end{array}$ \\
\hline A & 60,6 & $7,6^{3}$ & $94,89^{\circ}$ & 1289,82 & $1: 13,59$ \\
\hline B & 66,5 & $8,0^{n}$ & $118,61^{*}$ & $599,22^{6}$ & $1: 5,05$ \\
\hline C & 65,5 & $9,3^{2}$ & $201,20^{=}$ & $579,89^{\circ}$ & $1: 2,88$ \\
\hline D & 64,9 & $4,5^{5}$ & $77,31^{\circ}$ & $277,65^{2}$ & $1: 3,59$ \\
\hline
\end{tabular}

"Superskrip yang berbeda pada kolom yang sama menunjukkan perbedaan nyata $(\mathrm{P}<0,05)$.

"Different superscripts in the same collotumn show significant differences $(P<0.05)$.

Kandungan omega- 6 dalam kuning telur pada perlakuan A (wijen $4 \%$ ) sebesar $1289,82 \mathrm{mg} / 2$ butir telur lebih tinggi dibanding petlakuan B (wijen 2\%) scbesar $599,22 \mathrm{mg} / 2$ butir telur serta perlakuan $\mathrm{C}$ dan $\mathrm{D}$ (wijen $0 \%$ ) sebesar 579,89 dan $277,65 \mathrm{mg} / 2$ butir telur. Hal ini disebabkan karena ransum perlakuan A mengandung wijen paling tinggi, dan wijen merupakan sumber omega-6. Kandungan omega- 6 wijen sebesar $40,4 \%$ (Weiss dalam Kaul dan Das, 1986).

Perbandingan asam lemak omega-3 dan asam lemak omega-6 dalam kuring telur dipengaruhi oleh susunan ransum yang diberikan. Ransum perlakuan B dengan kerang gangsing sebesat $15 \%$ dan wijen $2 \%$ menghasilkan telur dengan imbangan kandungan asam lemak omega- 3 dan omega- 6 sebesar 1:5,05. Perbandingan tersebut sesuai dengan rekomendasi National Institute of Health Research and Development (1990) bahwa perbadingan omega- 3 dan omega- 6 . yang optimal bagi tubuh manusia adalah 1:4 sampai 1:8. Beda dengan hasil penelitian Sastrodihardjo et al. (1998) yang menggunakan minyak lemuru sebesar $4 \%$ sebagai sumber asam lemak omega-3 dan minyak sawit sebesar $2 \%$ scbagai sumber omega-6 dalam susunan ransum ayam petelur, menghasilkan asam lemak omega-3 sebesar $30,57 \mathrm{mg} / \mathrm{g}$ kuning telur dan asam lemak omega-6 scbesar $104,47 \mathrm{mg} / \mathrm{g}$ kuning telur. Perbandingan omega- 3 dan omega- 6 dalam penelitian ini adalah $1: 3,5$.

\section{Kesimpulan}

1. Penggunaan kerang gangsing sebesar $15 \%$ dan $30 \%$ dalam ransum itik dapat meningkatkan kandungan asam lemak omega-3 dalam kuning telur.

2. Penggunaan wijen $2 \%$ dan $4 \%$ dalam ransum itik meningkatkan kandungan asam lemak omega-6 dalam kuning telur. 
3. Perbandingan asam lemak omega-3 dan omega- 6 dalam kuning telur yang paling baik pada penggunaan kerang gangsing $15 \%$ dan wijen $2 \%$ dalam ransum.

\section{Daftar Pustaka}

Almatsier, S. 2003. Prinsip Dasar Ilmu Gizi. Cetakan kedua. PT: Gramedia Pustaka Utama. Jakarta.

Cherian, G. and J. Sim. 1992. Preferential Accumulation of Omega-3 Fatty Acids in the Brain of Chicks from Eggs with Fatty Acids. Poultry Science 71:16581668.

Chen, 1.f., A.J. Huang, C.Y. Lin, J.H. Lin, and C.C. Huang. 1999. The Effect of Dietary Fish Oil Emulsion on Omega 3 Polyunsaturated Fatty Acid in Duck Eggs. Proc. 1" World Waterfowl Conference. Taiwan. R.O.C.

Kaul, A.K. and M.I. Das. 1986. Oilseeds in Bangladesh. Bangladesh-Canada Agric. Sector. Team Ministry of Agric. Gov. of the People Rep. of Bangladesh. $13 \mathrm{p}$.

National Institute of Health Research and Development, 1990. Egg Science and Technology. 3rd Edition. Nutrition Research and Development Center. Bogor.

Oh, S.Y., C.H.H. Lin, J. Rayne, and D.E. Bell. 1994. Eggs Enriched with Omega 3 Fatty Acids as a Wholesome Food. J. Applied Nutrition 46:15-25.
Saroso, B. 1992. Identifikasi Asam Lemak pada Beberapa Minyak Nabati. Buletin Tembakau dan Serat 01:26-29.

Sastrodihardjo, S., D.M. Suci, dan M.N. Cahyanto. 1998. Penggunaan Minyak Ikan Lemuru dan Minyak Kelapa Sawil dalam Ransum terhadap Kandungan Asam Lemak Omega-3 dan Omega-6 dalam Kuning Telur Ayam. Proc. Seminar Nasional Peternakan dan Veteriner. Pusat Penelitian dan Pengembangan Peternakan, Bogor.

Soeharsono, N.K. Wardhani, E. Winarti, dan B. Prasetyo, 2002. Evaluasi Nutrisi "Gangsing" sebagai Sumber Pakan Lokal untuk Unggas di Kawasan Pantai Selatan DIY. Proc. Seminar Nasional Inovasi Teknologi dalam Mendukung Agribisnis. Puslitbang Sosial Ekonomi Pertanian. Bogor.

Soenardi dan Moch. Romli, 1996. Pasca Panen dan Pemanfaatan Wijen. Monograf. Balai Penelitian Tembakau dan Tanaman Serat. Malang.

Weiss, E.A. 1971. Castor, Sesame, and Safflower. Leonard Hill, London.

Winarti, E., N.K. Wardhani, dan A. Musofie, 2002. Pemanfaatan Gangsing (Sesarma reticulatum) sebagai Pakan Lokal untuk Substitusi Sebagian Sumber Protein dalam Ransum Itik. Proc. Seminar Nasional Inoyasi Teknologi dalam Mendukung Agribisnis. Puslitbang Sosial Ekonomi Pertanian. Bogor. 